\title{
U-PB LA-ICP-MS DATING OF ZIRCONS FROM SUBVOLCANICS OF THE BIMODAL DYKE SERIES OF THE WESTERN TRANSBAIKALIA: TECHNIQUE, AND EVIDENCE OF THE LATE PALEOZOIC EXTENSION OF THE CRUST
}

\author{
M. D. Buyantuev ${ }^{1}$, V. B. Khubanov ${ }^{1,2}$, T. T. Vrublevskayaa, ${ }^{1,2}$ \\ ${ }^{1}$ Geological Institute, Siberian Branch of RAS, Ulan-Ude, Russia \\ ${ }^{2}$ Buryat State University, Ulan-Ude, Russia
}

\begin{abstract}
Our study investigates a possibility of using isotope ratios of U-Th-Pb system in zircon analysis by the LA-ICP-MS technique and monitoring of precision, convergence and accuracy. New U-Pb isotope-geochronological data has been obtained for the salic and mafic members of the bimodal Late Paleozoic series of subparallel dykes in the central part of the Western Transbaikalia. It is shown that a series of subparallel dykes (290-280 Ma) gives evidence of extension of the continental crust at the final stage of the Late Paleozoic granitoid magmatism. Similar ages of zircons in the salic and mafic subvolcanic rocks confirm the geological indicators of the coexistence and interactions between the magmas of contrasting compositions.
\end{abstract}

\section{U-PВ LA-ICP-MS ДАТИРОВАНИЕ ЦИРКОНОВ ИЗ СУБВУЛКАНИТОВ БИМОДАЛЬНОЙ ДАЙКОВОЙ СЕРИИ ЗАПАДНОГО ЗАБАЙКАЛЬЯ: МЕТОДИКА, СВИДЕТЕЛЬСТВА ПОЗДНЕПАЛЕОЗОЙСКОГО РАСТЯЖЕНИЯ ЗЕМНОЙ КОРЫ}

\author{
М. Д. Буянтуев ${ }^{1}$, В. Б. Хубанов ${ }^{1,2}$, Т. Т. Врублевская ${ }^{1,2}$ \\ ${ }^{1}$ Геологический институт СО РАН, Улан-Удэ, Россия \\ 2 Бурятский государственный университет, Улан-Удэ, Россия
}

\section{RESEARCH ARTICLE}

Received: August 24, 2016

Recommended by E.V. Sklyarov

For citation: Buyantuev M.D., Khubanov V.B., Vrublevskaya T.T., 2017. U-Pb LA-ICP-MS dating of zircons from subvolcanics of the bimodal dyke series of the Western Transbaikalia: Technique, and evidence of the Late Paleozoic extension of the crust. Geodynamics \& Tectonophysics 8 (2), 369-384. doi:10.5800/GT-2017-8-2-0246.

Для цитирования: Буянтуев М.Д., Хубанов В.Б., Врублевская T.T. U-Pb LA-ICP-MS датирование цирконов из субвулканитов бимодальной дайковой серии Западного Забайкалья: методика, свидетельства позднепалеозойского растяжения земной коры // Геодинамика и тектонофизика. 2017. Т. 8. № 2. C. 369-384. doi:10.5800/GT-2017-8-2-0246. 
Аннотация: Оценена возможность использования изотопных отношений U-Th-Pb системы при анализе цирконов методом LA-ICP-MS путем мониторинга прецизионности, сходимости и правильности. Получены новые $\mathrm{U}-\mathrm{Pb}$ изотопно-геохронологические данные для салических и мафических членов бимодальной позднепалеозойской серии субпараллельных даек центральной части Западного Забайкалья. Показано, что формирование серии субпараллельных даек (290-280 млн лет назад) фиксирует условия растяжения континентальной коры на заключительном этапе позднепалеозойского гранитоидного магматизма. Близкий возраст цирконов салических и мафических субвулканитов подтверждает геологические признаки сосуществования и взаимодействия контрастных магм.

Ключевые слова: LA-ICP-MS; U-Pb датирование; бимодальная серия; дайковый пояс; растяжение коры; Забайкалье; смешение магм

\section{1. ВВЕДЕНИЕ}

Наряду с многочисленными массивами щелочных гранитоидов и полями бимодальных вулканитов в Забайкалье широко распространены ассоциации субпараллельных даек. По крайней мере, часть этих даек группируется в протяженные дайковые пояса, обычно считающиеся индикаторами внутриплитного растяжения, что делает их важным «репером» при палеогеодинамических реконструкциях. Кроме того, дайки представляют собой важный источник информации о процессах магмогенерации. Например, наличие даек с признаками взаимодействия контрастных жидкостей позволяет оценить возможность формирования средних, промежуточных, типов пород при химическом смешении мафических и кислых магм [Wiebe, Ulrich, 1997; Katzir et al., 2007; Sklyarov, Fedorovskii, 2006; Vrublevskaya et al., 2013; Khubanov et al., 2015].

Следует отметить, что из-за отсутствия надежных геологических, вещественных и геохронологических критериев расчленения даек и их скоплений они представляются малоизученными. Зачастую вопрос о возрасте даек является ключевым и остается открытым ввиду невозможности использования относительных методов и ограничений абсолютных методов датирования. В частности, применение традиционных изотопных (Rb-Sr, $\mathrm{Sm}-\mathrm{Nd}, \mathrm{K}-\mathrm{Ar}$ ) методов датирования субвулканитов осложнено низкой сохранностью породообразующих минералов, кристаллизованных из магмы, трудностью выделения минеральных монофракций из тонко- и мелкозернистого субстрата, необходимостью принятия предположения о родстве ассоциирующих пород априори в случае их датирования по валовым изотопным составам. В связи с этим для геохронологии субвулканитов предпочтительно использование локальных изотопных методов датирования минералов, устойчивых к вторичным преобразованиям. Одним из таких методов является U-Pb изотопное датирование цир- кона, наиболее химически устойчивого минерала в широком диапазоне Р-Т условий, с помощью лазерной абляции и масс-спектрометрии с индуктивносвязанной плазмой (LA-ICP-MS). Этот метод характеризуется высоким пространственным разрешением, а также представляется относительно экспрессным, бюджетным и доступным.

В работе приведены результаты датирования цирконов из позднепалеозойской бимодальной ассоциации субпараллельных даек, образующих протяженный пояс в центральной части Западного Забайкалья, полученные с помощью $\mathrm{U}-\mathrm{Pb}$ изотопного LA-ICP-MS метода. Кроме того, на основе статистической обработки накопленной базы изотопных данных по эталонным цирконам сопоставлены возможности использования изотопных отношений U-Th-Pb систем, измеренных LA-ICP-MS методом.

\section{2. ГЕОЛОГИЧЕСКОЕ СТРОЕНИЕ}

Значительная часть территории Западного Забайкалья, более 200 тыс. км², сложена разнотипными гранитоидами позднепалеозойского возраста, которые принадлежат к пяти интрузивным комплексам [Tsygankov et al., 2010]. В порядке формирования это: 1) баргузинский комплекс (330-300 млн лет), включающий известково-щелочные автои аллохтонные биотитовые граниты, слагающие крупнейший в мире Ангаро-Витимский батолит [Litvinovsky et al., 1993]; 2) чивыркуйский комплекс (305-285 млн лет) - высококалиевые кварцевые монцониты, кварцевые сиениты и габброиды; 3) зазинский комплекс (305-285 млн лет) - переходные от известково-щелочных к субщелочным граниты и кварцевые сиениты; 4) нижнеселенгинский комплекс (285-278 млн лет) - высококалиевые (шошонитовые) кварцевые сиениты, монцониты и габброиды; 5) раннекуналейский комплекс (281-278 млн лет) - щелочные и щелочно- 


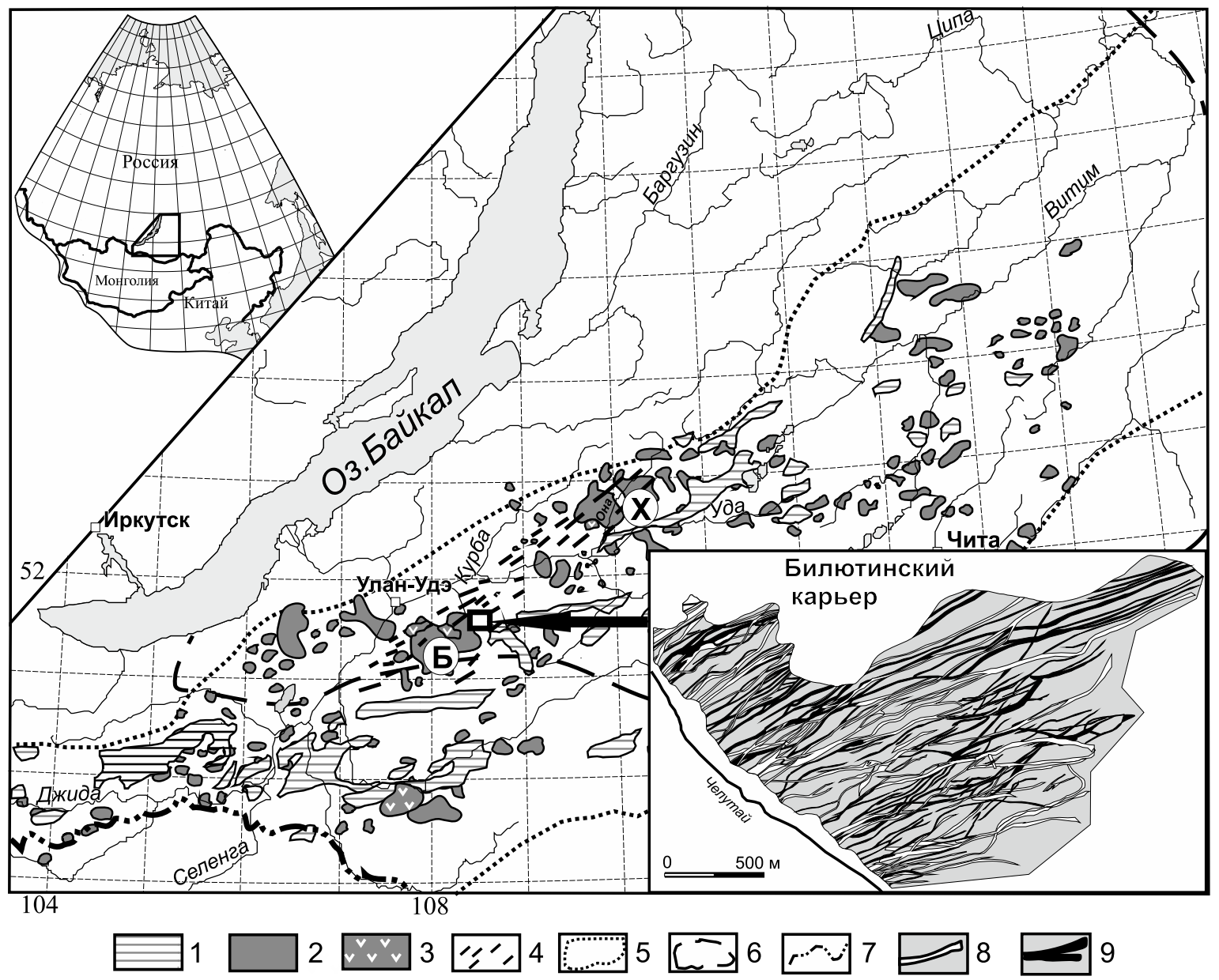

Рис. 1. Схема распространения позднепалеозойских - мезозойских магматических ассоциаций в Западном Забайкалье.

1 - позднеюрские - раннемеловые вулканиты по [Yarmolyuk et al., 1998]; 2 - пермь-триасовые щелочные гранитоиды по [Zanvilevich et al., 1985]; 3 - пермские вулканиты; 4 - позднепалеозойский бимодальный дайковый пояс; 5 - контуры полихронной $\mathrm{PZ}_{3}-\mathrm{KZ}$ рифтовой зоны; 6 - контуры позднепалеозойского Ангаро-Витимского батолита; 7 - государственная граница; Б в кружке - Брянский массив гранитоидов повышенной щелочности; X - Хоринский массив гранитоидов повышенной щелочности. В нижнем правом углу - фрагмент бимодального дайкового пояса, Билютинский известняковый карьер (с упрощениями по неопубликованным данным Н.А. Фишева и В.А. Ананина), где 8 - салические дайки; 9 - мафические дайки.

Fig. 1. Scheme showing the occurrence of the Late Paleozoic-Mesozoic magmatic associations in the Western Transbaikalia.

1 - Late Jurassic - Early Cretaceous volcanic rocks after [Yarmolyuk et al., 1998]; 2 - Permian - Triassic alkaline granitoids after

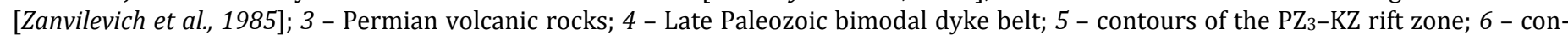
tours of the Late Paleoizoic Angara-Vitim batholith; 7 - the state border; 5 (in the circle) - Bryansk granitoids of high alkalinity; $\mathrm{X}$ - Khorinsky granitoids of high alkalinity. Lower right corner - fragment of the bimodal dyke belt, Biluta limestone quarry (simplified, based on the unpublished data by N.A. Fishev and V.A. Ananin): 8 - salic dykes; 9 - mafic dykes.

полевошпатовые граниты и сиениты. Несмотря на значительное или даже полное перекрытие значений абсолютного возраста комплексов, принятая последовательность их становления основана на геологических взаимоотношениях.

В центральной части Западного Забайкалья распространены многочисленные дайки. Они образуют дайковый пояс, который простирается более чем на 200 км от устья р. Хилок до верховьев р. Она, при общей ширине около 40 км (рис. 1) [Khubanov, 2009]. Дайки на разных участках пояса представле- ны скоплениями субпараллельных тел с северовосточным (50-70) генеральным простиранием, нередко пакетированных, т.е. настолько близко расположенных друг к другу, что вмещающие породы слагают лишь узкие промежутки между ними и по своей ширине сопоставимы с мощностью даек (от первых метров до 10-15 м). В среднем плотность распространения дайковых тел составляет 10-20 \% от объема всех пород, до сотни тел на километр, но может достигать 70-80 \%; нередко наблюдаются комплексы «дайка в дайке». Послед- 
M.D. Buyantuev et al.: U-Pb LA-ICP-MS dating of zircons from subvolcanics of the bimodal dyke series of the Western Transbaikalia...

ние характеризуются образованием полудаек (с наличием эндоконтакта только с одной стороны) и скринов (полное отсечение эндоконтактов поздними инъекциями дайковых магм). По составу дайки представлены трахибазальтами и трахидолеритами и их плагиофировыми разностями (мегаплагиофировыми лейкобазальтами), кварцевыми трахитами, щелочно-полевошпатовыми трахитами и риолитами, щелочными трахитами и риолитами, которые составляют субвулканическую бимодальную трахибазальт-трахит-трахириолитовую серию с подчиненным количеством трахиандезитовых даек. Соотношение мафических и салических даек варьируется на разных участках, но в целом преобладают салические разности.

Наблюдения за взаимоотношениями даек различного состава показали, что образование мафических и салических даек происходило практически одновременно, о чем свидетельствуют взаимные пересечения и повсеместно распространенные в пределах пояса комбинированные дайки с признаками смешения контрастных магм.

Дайковый пояс пространственно сопряжен с двумя крупнейшими многофазными щелочно-гранитоидными плутонами - Брянским и Хоринским, площадь каждого не менее 1500 км². Оба плутона вместе с ассоциирующими бимодальными трахибазальт-комендитовыми вулканитами образуют одноименные вулканоплутонические ассоциации, традиционно относимые к Монголо-Забайкальской щелочно-гранитоидной провинции [Zanvilevich et $a l ., 1985]$. В пределах гранитоидов повышенной щелочности дайки отмечены в меньшем количестве, в виде скоплений по 10-20 трахибазальтовых, трахитовых и трахириолитовых субпараллельных тел северо-восточного простирания. Состав субвулканической серии, в том числе даек, секущих Брянский и Хоринский массивы, во многом схож с составом указанных плутонических и вулканических образований [Khubanov, 2009].

Ассоциации гранитов повышенной щелочности и бимодальных вулканитов сформировались на позднепалеозойском этапе 285-280 млн лет назад [Litvinovsky et al., 2002; Posokhov et al., 2005; Reichow et al., 2010]. Согласно геологическим наблюдениям, щелочные гранитоиды и дайки пояса имеют секущее положение по отношению к раннепалеозойским(?) метаморфическим породам, гранитам баргузинского и зазинского комплексов. Ранее предпринимались попытки установления возраста формирования пояса с помощью $\mathrm{Rb}-\mathrm{Sr}$ изотопного метода датирования салических даек и были получены карбон-пермские значения [Shadaev et al., 2005; Posokhov et al., 2005; Khubanov, 2009].

Необходимо отметить, что в пределах пояса повсеместно, но редко распространены комбиниро- ванные (сложные) дайки. Среди них, согласно [Wiebe, Ulrich, 1997], выделено два типа: 1) дайки с caлической краевой частью и существенно мафической центральной, представляющей собой пиллоуподобные или неправильной формы базальтовые обособления (глобулы), сцементированные салическим материалом; 2) дайки с мафическими (базальтовыми) краевыми зонами и салической, преобладающей по объему, центральной частью. Между ними постепенный переход, что указывает на интенсивное взаимодействие контрастных магм.

Одним из примеров комбинированной дайки второго типа является тело в центральной части дайкового пояса, в пределах Билютинского известнякового карьера (рис. 2) [Vrublevskaya et al., 2013]. Мощность дайки варьируется от 12 м на нижнем горизонте карьера до 10 м в верхней части обнажения. Центральная часть комбинированной дайки представлена трахириолитами, краевые части трахибазальтами (рис. 2). На контакте с вмещающими породами в трахибазальтах отчетливо просматривается эндоконтактовая афанитовая зона закалки мощностью около 10 см. Переход между трахибазальтовыми краевыми и трахириолитовой центральной частью постепенный, без видимых резких границ. Мощность переходной зоны достигает 1 м. Трахириолиты центральной части дайки содержат редкие базитовые включения овальной и округлой формы, количество которых заметно возрастает в переходной зоне, с приближением к краевому трахибазальту. Последние петрографически близки к афанитовым трахибазальтам, но в них немного больше тонкозернистого магнетита. Переходная зона содержит видимые розовые вкрапленники K-Na полевого шпата размером до 7-8 мм по длинной оси, количество которых к периферии дайки быстро уменьшается, вплоть до полного исчезновения в трахибазальтах - в 30-40 см от контакта с известняками. Подобное геологическое строение сложной дайки указывает на образование пород переходной зоны, трахиандезитов и трахидацитов в результате химического in situ смешения трахибазальтовой и трахириолитовой магм [Vrublevskaya et al., 2013].

\section{3. МЕТОДИКА ДАТИРОВАНИЯ}

Подготовка цирконов. Выделение цирконов велось по методике, которая включала в себя несколько этапов дробления и просеивания породы, сепарацию по магнитным свойствам и плотности. Затем зерна вручную отбирались под бинокуляром, ополаскивались деионизированной водой в ультразвуковой ванне и фиксировались в эпоксидной смоле, после чего подверглись шлифованию до 

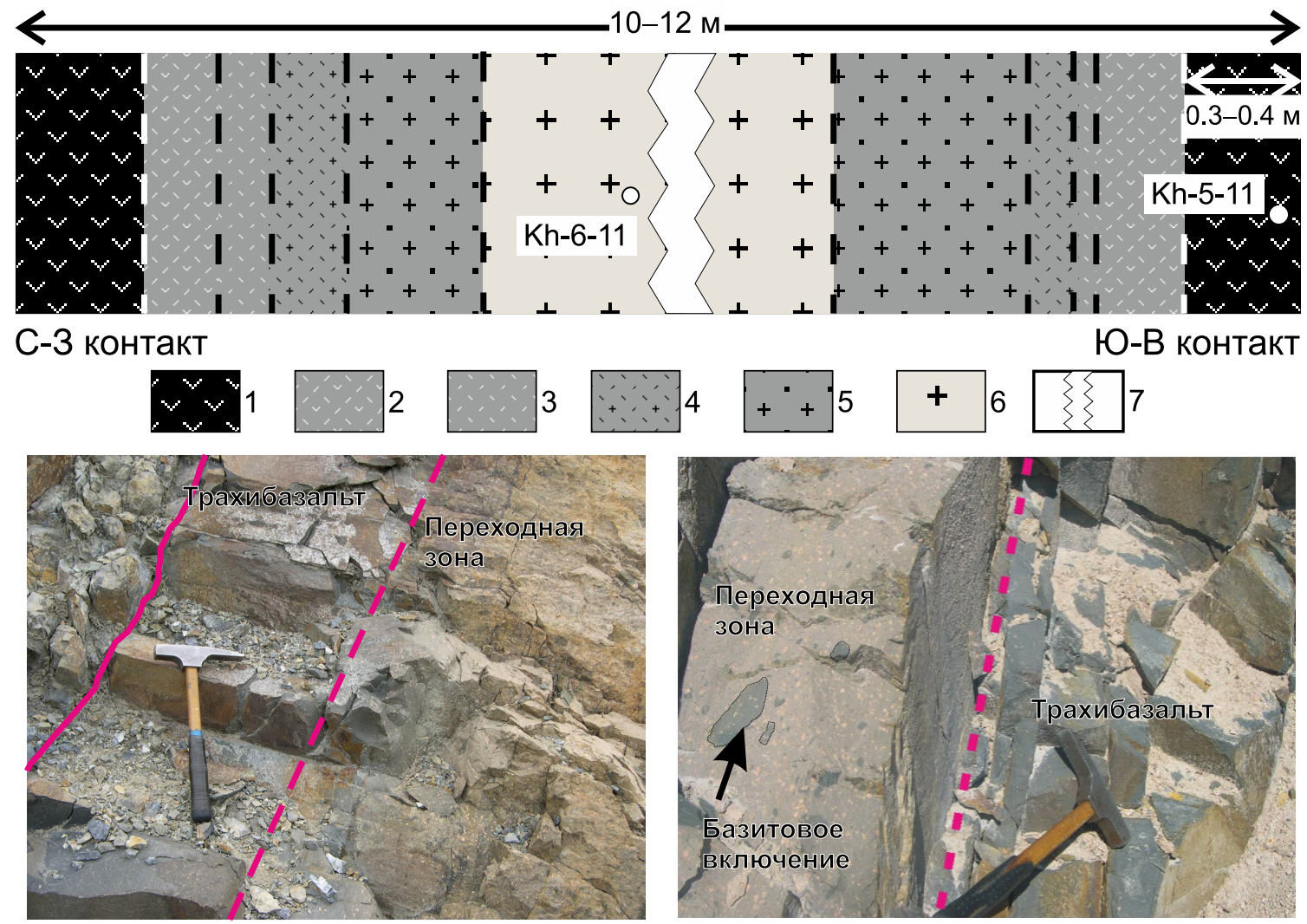

Рис. 2. Схематическая зарисовка строения комбинированной дайки с признаками химического смешения контрастных магм, Билютинский карьер.

1 - трахибазальтовая краевая зона; 2-5 - переходная зона: 2 - трахиандезибазальт, 3 - трахиандезит, 4 - трахидацит, 5 - трахириодацит; 6 - трахириолитовая центральная зона дайки; 7 - разрыв разреза. Пунктирными линиями показан постепенный переход между породами различного состава. Места отбора материала для датирования обазначены кружками и подписями с номерами проб. Внизу - фотографии переходных зон.

Fig. 2. Schematic structure of the combined dyke with signs of chemical mixing of contrasting magmas, Biluta quarry.

1 - trachybasaltic marginal zone; 2-5 - transition zone: 2 - trachyandesite basalt, 3 - trachyandesite, 4 - trahidazite, 5 - trahiriodazite; 6 - trachyriolithic central zone of dykes; 7 - cut of the profile. Dashed lines show the gradual transition between rocks of different compositions. The sampling sites are marked by circles showing names and sample numbers. Below are photos of the transitional zones.

выведения зерен на поверхность и полировке. Готовый препарат представлял собой цилиндр с диаметром 25 мм и высотой не более 8 мм. Для стандартных цирконов был приготовлен отдельный препарат, также цилиндрической формы, диаметром 10 мм и высотой менее 8 мм.

Оборудование и параметры настроек. $\mathrm{U}-\mathrm{Pb}$ изотопный анализ выполнен на масс-спектрометре высокого разрешения Element XR (Thermo Fisher Scientific), соединенном с приставкой лазерного проботбора UP-213 (New Wave Research) с длиной волны излучения 213 нм в лаборатории инструментальных методов анализа Геологического института Сибирского отделения РАН (ГИН СО РАН, г. Улан-Удэ).

Операционные параметры и конфигурация оборудования для анализа в большинстве своем были идентичны тем, что приведены в [Khubanov et al.,
2016] (таблица). Индуктивно-связанная плазма образовывалась в кварцевой горелке с кварцевым распылителем с диаметром 1.7 мм, в котором происходила ионизация частиц пробы. Выделение узкого прямолинейного пучка ионов для анализа и отвод излишков пробы проводились с помощью системы алюминиевых конусов. Основные операционные параметры масс-спектрометра настраивались по раствору индия с концентрацией $1 \mathrm{ppb}$, для которого достигался сигнал не менее $10^{6} \mathrm{cps}$ и/или урана (1 ppb) - не менее $1.2 \cdot 10^{6} \mathrm{cps}$. После этого подбирались условия расходования аргона и гелия, а также напряжение на индукционную катушку при лазерном испарении циркона Plešovice. Оптимальными условиями считались настройки (таблица), при которых наблюдался максимальный сигнал изотопов ${ }^{206} \mathrm{~Pb}$ и ${ }^{238} \mathrm{U}$ при абляции стандартного циркона, при минимальном значении отно- 


\section{Параметры настроек оборудования LA-ICP-MS для U-Pb изотопного датирования цирконов}

\section{Parameters of LA-ICP-MS equipment settings for U-Pb isotope dating of zircons}

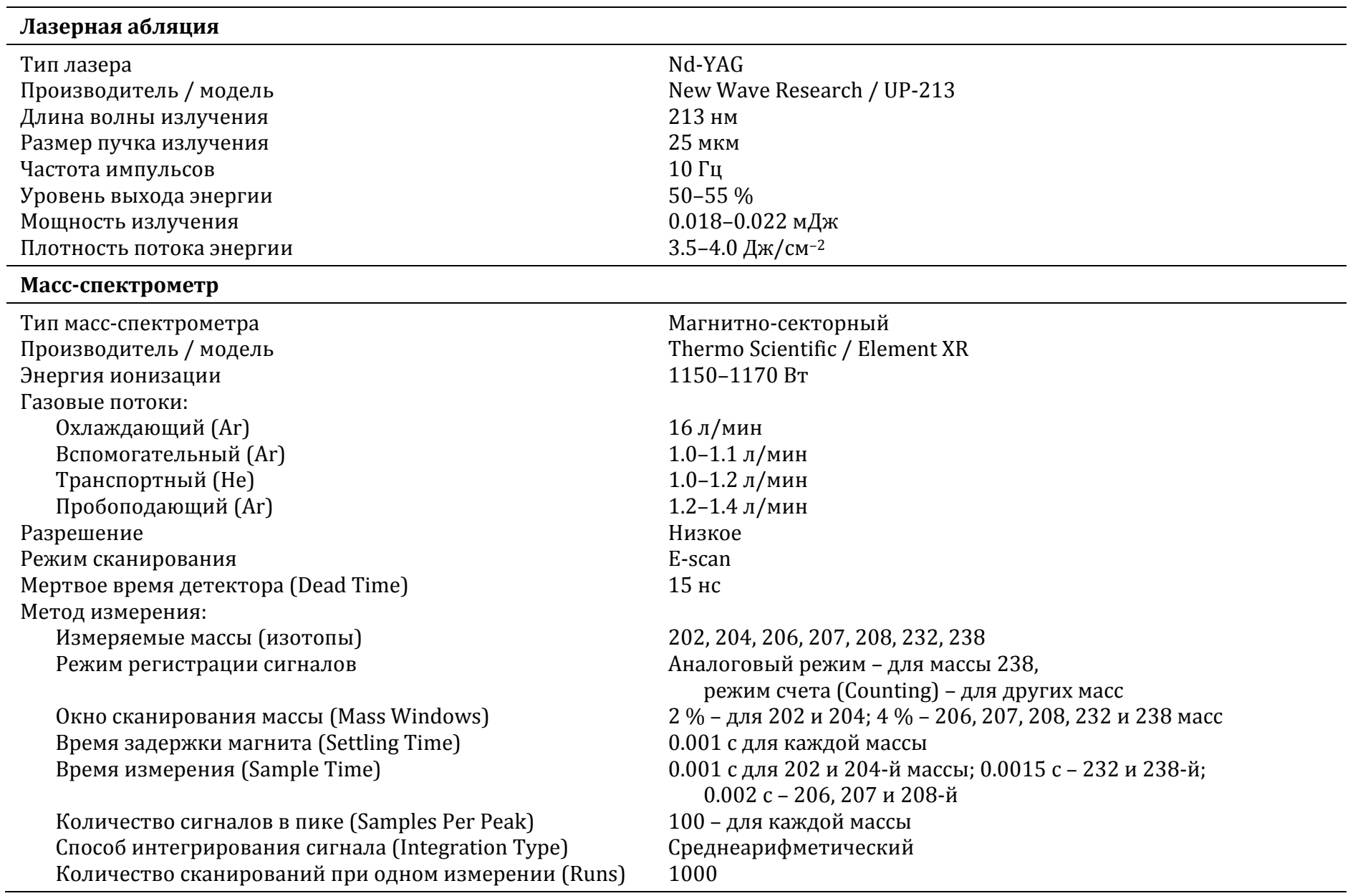

шения $238 \mathrm{U}^{16} \mathrm{O}^{+} / 238 \mathrm{U}^{+}$, менее 4 \%. Съемка проводилась в скоростном режиме электростатического сканирования (E-scan). Диапазон беспрерывного Escan сканирования масс (от 202 до 238 а.е.м.) позволял производить измерения сигналов изотопов без переключения магнитного поля.

Масс-спектрометром измерялись сигналы следующих изотопов: ${ }^{202} \mathrm{Hg},{ }^{204}(\mathrm{Hg}+\mathrm{Pb}),{ }^{206} \mathrm{~Pb},{ }^{207} \mathrm{~Pb}$, $208 \mathrm{~Pb},{ }^{232} \mathrm{Th}, 238 \mathrm{U}$ (таблица). Сигнал $235 \mathrm{U}$ рассчитывался из сигнала ${ }^{238} \mathrm{U}$, основываясь на постоянстве современного значения их отношения $(238 \mathrm{U} / 235 \mathrm{U}=$ =137.88). Детектирование сигналов проводилось в режиме счета (Counting), кроме изотопа ${ }^{238 \mathrm{U}}$ (в режиме «Analog»).

Процедура измерения и расчета. При проведении измерений неизвестных проб выстраивалась следующая аналитическая последовательность: в начале и в конце - по четыре измерения первого (внешнего) стандарта и по два измерения второго (контрольного) стандарта, далее через каждые пять измерений неизвестных образцов проводилось по одному измерению первого и второго стандарта. Перед началом каждой сессии изотоп- ного анализа выполнялась последовательность, состоящая из десяти измерений внешнего стандарта и десяти измерений контрольного образца для контроля настроек физических параметров LA-ICP-MS системы.

Обработка данных анализа выполнена в программах Glitter [Van Achterbergh et al., 2001; Griffin et al., 2008] и Microsoft Excel с надстройкой Isoplot [Ludwig, 2008]. При этом в качестве внешнего стандарта использовались цирконы Temora 2 [Black et al., 2004] (до сентября 2015 г.) и 91500 [Wiedenbeck et al., 1995] (с сентября 2015 г. по настоящее время), в качестве контрольного образца во всех анализах использовался циркон Plešovice [Sláma et al., 2008].

Традиционно поправка на обыкновенный (общий, нерадиогенный, первозданный) свинец при $\mathrm{U}-\mathrm{Pb}$ анализе проводится с помощью нерадиоген-

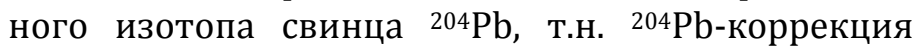
[Williams, 1998; Košler, Sylvester, 2003], которая считается наиболее приемлемой ввиду того, что не подразумевает абсолютной конкордантности изотопных отношений. Однако в LA-ICP-MS использо- 

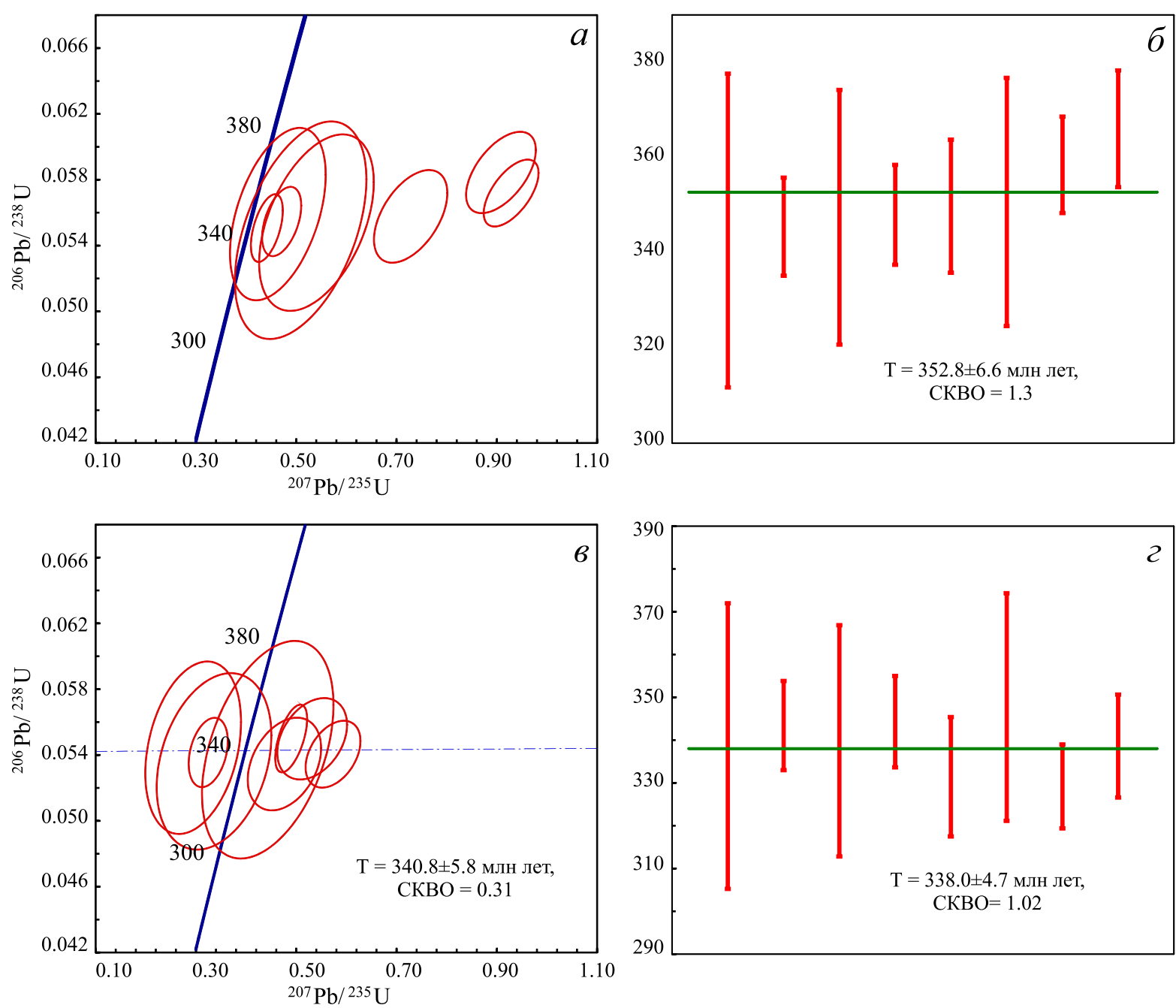

Рис. 3. Диаграммы с конкордией и диаграммы средневзвешенных возрастов для восьми локальных U-Pb LA-ICP-MS анализов циркона Plešovice, с примесью обыкновенного свинца: $a, \sigma$ - до коррекции на обыкновенный свинец; в после ${ }^{204} \mathrm{~Pb}$-коррекции; 2 - после ${ }^{207} \mathrm{~Pb}$-коррекции. Эллипсы и планки погрешностей на уровне $2 \sigma$.

Fig. 3. Diagrams with concordia and average weighted ages of eight local U-Pb LA-ICP-MS tests of zircon Plešovice with an

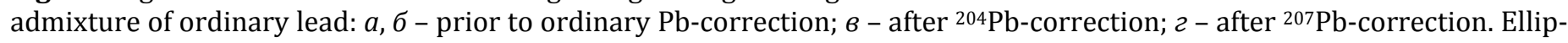
ses and error bars are at the level $2 \sigma$.

вание этого метода не всегда возможно из-за низкого содержания изотопа ${ }^{204} \mathrm{~Pb}$, в том числе вследствие его низкой природной распространенности, а также высокого предела его обнаружения при анализе из-за спектрального наложения сигнала изотопа ртути ${ }^{204} \mathrm{Hg}$, который присутствует в пробонесущем инертном газе Не. Эти факторы создают трудности для корректного определения сигнала $204 \mathrm{~Pb}$. С целью снижения содержания примесей на газовые магистрали обычно устанавливаются ртутьулавливающие ловушки (золотые, угольные), как, например, в [Hirata et al., 2005; Gehrels et al., 2008]. Но даже с применением фильтров не всегда возможно точное определение сигнала свинца ${ }^{204} \mathrm{~Pb}$, поэтому в методах локального датирования широкое распространение получили поправки на обык- новенный свинец с помощью ${ }^{207} \mathrm{~Pb}$-метода коррекции [Williams, 1998]. Суть этой коррекции достаточно подробно описана, например, в работе [Chew et al., 2011]. Однако нужно учитывать, что применение этого метода коррекции возможно в том случае, если U-Pb изотопная система не претерпела никаких нарушений и оставалась закрытой, т.е. наблюдаемая дискордантность измеренных данных является следствием наличия обыкновенного свинца.

На рис. 3 приведены примеры введения коррек-

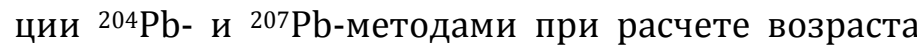
контрольного образца циркона Plešovice, где имелась примесь обыкновенного свинца, изотопный состав которого принят по модели Стейси и Крамерса [Stacey, Kramers, 1975]. Показано, что ${ }^{207} \mathrm{~Pb}$-коррекция для ${ }^{206} \mathrm{~Pb} /{ }^{238} \mathrm{U}$ возраста дает более 

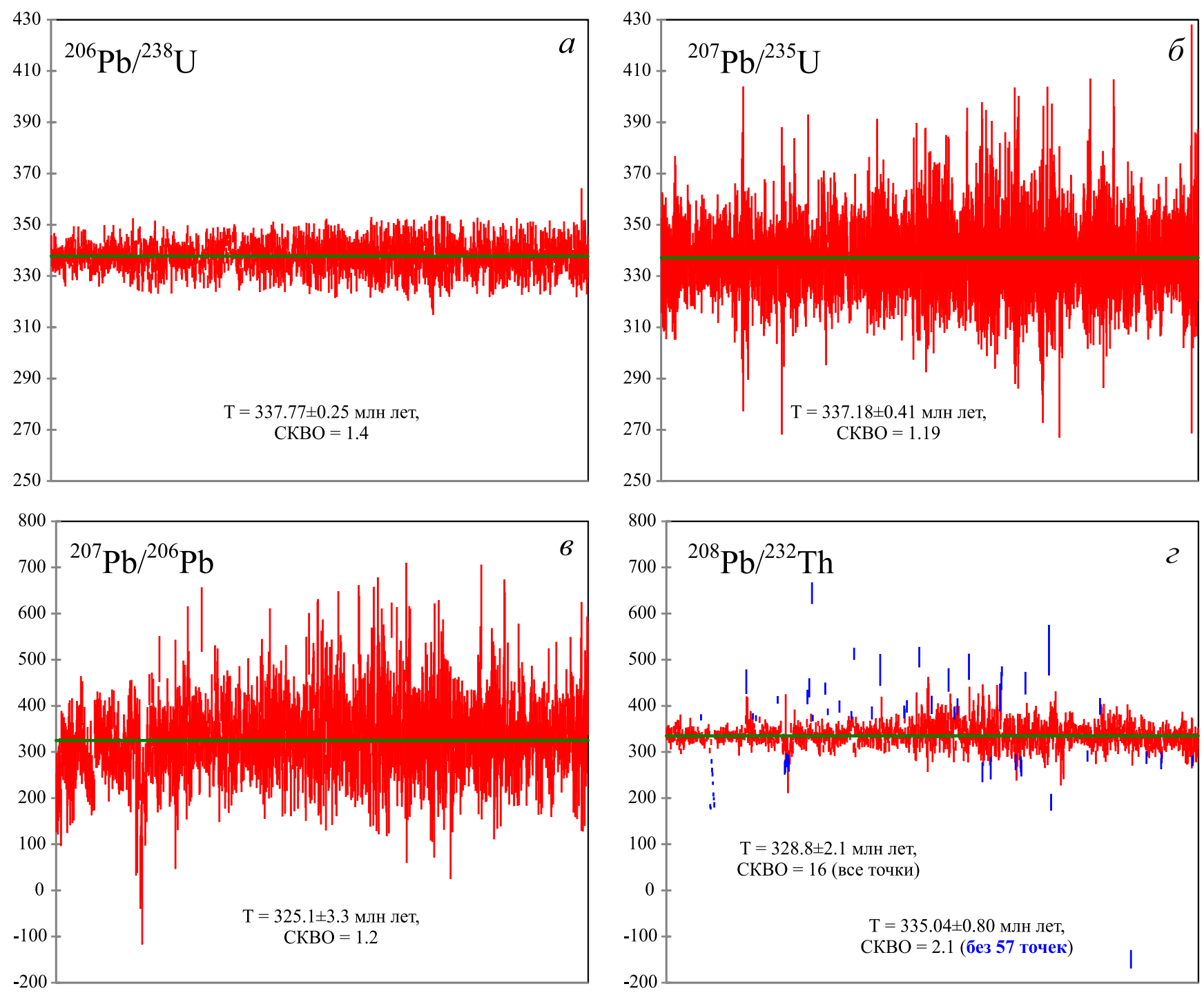

Рис. 4. Средневзвешенный возраст по изотопным отношениям U-Th-Pb системы на основе 1198 точек анализа на цирконе Plešovice: $a-{ }^{206} \mathrm{~Pb} /{ }^{238} \mathrm{U}, 6-{ }^{207} \mathrm{~Pb} /{ }^{235} \mathrm{U}$, в $-{ }^{207} \mathrm{~Pb} /{ }^{206} \mathrm{~Pb}, 2-{ }^{208} \mathrm{~Pb} /{ }^{232} \mathrm{Th}$. Планки погрешностей на уровне $2 \sigma$.

Fig. 4. Average weighted ages from isotopic ratios of $\mathrm{U}-\mathrm{Th}-\mathrm{Pb}$ system based on 1198 analysis points on zircon Plešovice: $a-{ }^{206} \mathrm{~Pb} /{ }^{238} \mathrm{U}, \sigma-{ }^{207} \mathrm{~Pb} /{ }^{235} \mathrm{U}, \boldsymbol{в}-{ }^{207} \mathrm{~Pb} /{ }^{206} \mathrm{~Pb}, 2-{ }^{208} \mathrm{~Pb} /{ }^{232}$. Error bars are at the level $2 \sigma$.

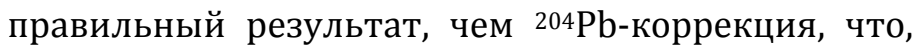
вероятно, обусловлено некорректным анализом изотопа ${ }^{204} \mathrm{~Pb}$ по причине его слабого сигнала.

Правильность анализа и особенности использования U-Th-Pb изотопной системы. Погрешности измерения изотопных отношений контрольного образца циркона Plešovice, полученные при датировании каждой геологической пробы, характеризующие прецизионность, варьируются в пределах (на уровне 2б): 0.80-2.45 \% для ${ }^{206} \mathrm{~Pb} / 238 \mathrm{U} ; 2.12-$

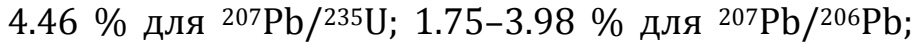
2.17-10.86 \% для ${ }^{208} \mathrm{~Pb} /{ }^{232} \mathrm{Th}$. При этом значения средневзвешенного возраста по этим отношениям для циркона Plešovice (аттестованное значение

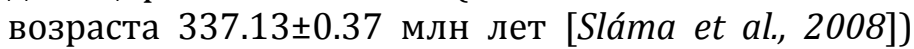
составляют: 332.6-336.9 млн лет для $206 \mathrm{~Pb} / 238 \mathrm{U}$;

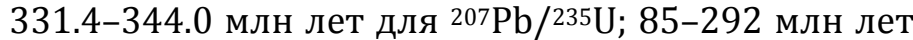
для $207 \mathrm{~Pb} / 206 \mathrm{~Pb} ; 319.4-350.0$ млн лет ${ }^{208} \mathrm{~Pb} /{ }^{232} \mathrm{Th}$. Оценки возраста по первым двум отношениям попадают в 2\%-ный диапазон погрешности от аттестованного значения возраста стандарта.

На рис. 4 приведена статистика определения возраста по четырем изотопным отношениям U-Th-Pb системы при датировании стандартного циркона Plešovice в качестве контрольного образца за период 2015 г. - начало 2016 г., которая позволяет оценить сходимость анализов в долгосрочном периоде. За это время было выполнено 1198 локальных анализов данного стандарта.

Средневзвешенный возраст по изотопному отношению ${ }^{206} \mathrm{~Pb} / 238 \mathrm{U}$ составил $337.77 \pm 0.25$ млн лет (рис. $4, a$ ), по $207 \mathrm{~Pb} / 235 \mathrm{U}-337.18 \pm 0.41$ млн лет 
(рис. 4, б), по $207 \mathrm{~Pb} / 206 \mathrm{~Pb}-325.1 \pm 3.3$ млн лет (рис. 4, в). Нужно отметить, что для стандарта Plešovice в [Sláma et al., 2008] данные по ${ }^{208 \mathrm{~Pb} /{ }^{232} \mathrm{Th}}$ не приведены, для этого отношения нами получено значение средневзвешенного возраста $328.8 \pm 2.1$ млн лет (рис. 4,2$)$. Однако здесь наблюдаются точки с существенным отклонением, контрастно отличающимся от основной группы относительно кучно расположенных данных. Если при определении средневзвешенного возраста применить опцию программы Isoplot, которая исключает из расчета наиболее отклоняющиеся данные (поставлена галочка напротив пункта «Reject OK?» в главном диалоговом окне), то не принимаются в расчет 57 (выделены синим цветом) точек, и средневзвешенный возраст по оставшимся данным составит $335.04 \pm 0.8$ млн лет (рис. 4,2$)$.

Представленные данные свидетельствуют о том, что наименьшим разбросом, а соответственно наилучшей точностью и правильностью, обладают

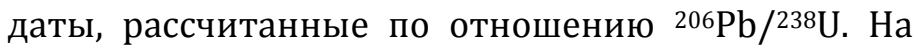
втором месте - данные по отношению ${ }^{207} \mathrm{~Pb} /{ }^{235} \mathrm{U}$. Здесь как разброс самих значений возраста, так и размер $2 \sigma$ погрешностей выше, чем в предыдущем случае, примерно в два раза. Существенное отклонение значений возраста и относительно большие значения $2 \sigma$ погрешностей наблюдаются для дат по отношению ${ }^{207} \mathrm{~Pb} / 206 \mathrm{~Pb}$. По отношению $208 \mathrm{~Pb} / 232 \mathrm{Th}$ наблюдаются точки с существенным отклонением от среднего значения, однако они контрастно отличаются от основной группы относительно кучно расположенных данных.

Подобная разница значений дат и их погрешностей, рассчитанных по изотопным отношениям ${ }^{206} \mathrm{~Pb} /{ }^{238} \mathrm{U},{ }^{207} \mathrm{~Pb} /{ }^{235} \mathrm{U},{ }^{207} \mathrm{~Pb} /{ }^{206} \mathrm{~Pb}$ и ${ }^{208} \mathrm{~Pb} /{ }^{232} \mathrm{Th}$, повидимому, обусловлена природными особенностями изотопных систем (период полураспада и геохимические свойства).

Для изотопов урана и тория периоды полураспада $\mathrm{T}_{1 / 2}$ (или постоянная распада $\lambda$ ) имеют значения: $232 \mathrm{Th}-14.01$ млрд лет $\left(4.9475 \times 10^{-11} \mathrm{c}^{-1}\right)$; ${ }^{238} \mathrm{U}-4.468$ млрд лет $\left(1.55125 \times 10^{-10} \mathrm{c}^{-1}\right),{ }^{235} \mathrm{U}-0.704$ млрд лет $\left(9.8485 \times 10^{-10} \mathrm{c}^{-1}\right)$. Согласно закону радиоактивного распада изотопное отношение дочерний/материнский связано с возрастом минерала (время, которое прошло с момента закрытия изотопной системы) логарифмической зависимостью:

$$
\text { возраст }=\ln (\text { отношение }+1) / \lambda \text {, }
$$

где $\lambda$ - постоянная распада материнского изотопа.

На рис. 5 приведен график этой функции для изотопных отношений U-Th-Pb системы, который показывает, что изменение изотопного отношения на одно и то же значение происходит за разный

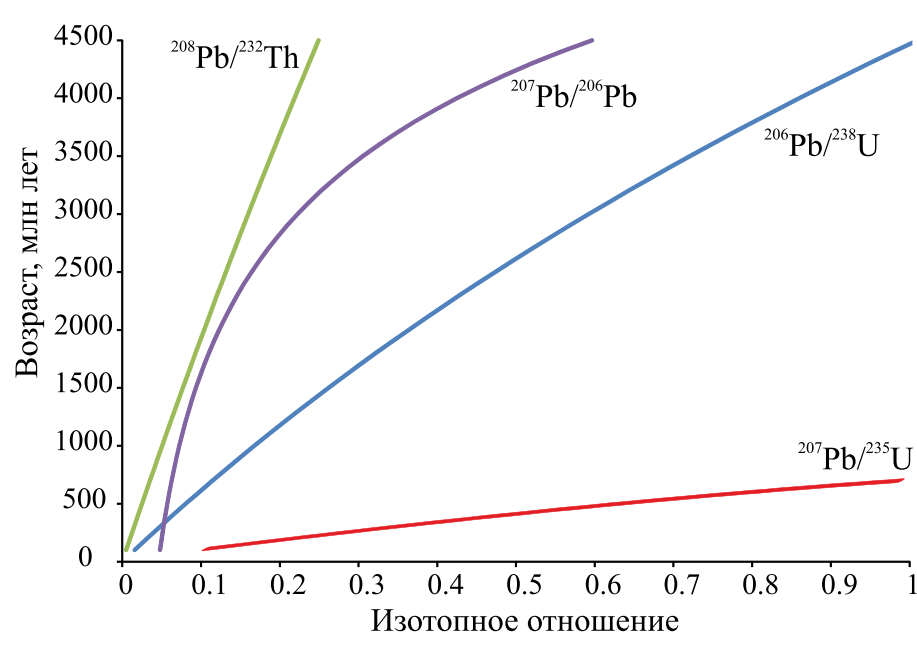

Рис. 5. Кривые зависимости возраста минерала от отношения дочернего изотопа к материнскому U-Th-Pb системы согласно закону радиоактивного распада.

Fig. 5. Ages of the minerals versus the ratio of the subsidiary isotope to the parent isotope of $\mathrm{U}-\mathrm{Th}-\mathrm{Pb}$ system in accordance with the law of radioactive decay.

промежуток времени ввиду разницы постоянной распада.

Распад 235U является самым быстрым, поэтому изменение изотопного отношения ${ }^{207} \mathrm{~Pb} / 235 \mathrm{U}$ происходит за наименьшее время (рис. 5). В связи с этим ошибка инструментального определения изотопного отношения будет меньше влиять на вычисление датировки. Однако из-за малой природной распространенности материнского изотопа $235 \mathrm{U}$ и низкого содержания его дочернего изотопа ${ }^{207} \mathrm{~Pb}$ и соответственно сложности инструментального измерения низких концентраций отношение ${ }^{207} \mathrm{~Pb} /{ }^{235} \mathrm{U}$ является не самым надежным для датирования.

Кривая отношения ${ }^{207} \mathrm{~Pb} / 206 \mathrm{~Pb}$ представляется наиболее изменчивой (рис. 5): обладает крутым наклоном для молодых возрастов и становится пологой к древним возрастам. Это означает, что для молодых цирконов даже незначительное отклонение измеренного изотопного отношения от истинного значения может привести к существенному искажению возраста. В области дофанерозойских возрастов наклон кривой меняется на более пологий, а также содержание дочерних изотопов ${ }^{207} \mathrm{~Pb}$ и ${ }^{206} \mathrm{~Pb}$ со временем увеличивается. Первое приводит к тому, что снижается «чувствительность» значения возраста к правильности определения отношения ${ }^{207} \mathrm{~Pb} / 206 \mathrm{~Pb}$, а второе - к увеличению надежности инструментального определения данного отношения ввиду того, что изотопы свинца в древних цирконах при анализе дают более высокий сигнал. Исходя из этого изотопное отношение 
M.D. Buyantuev et al.: U-Pb LA-ICP-MS dating of zircons from subvolcanics of the bimodal dyke series of the Western Transbaikalia...

${ }^{207} \mathrm{~Pb} / 206 \mathrm{~Pb}$ берется за основу для датирования древних цирконов, а примерным «порогом» надежности применения, согласно [Gehrels et al., 2008], считается возраст 1 млрд лет.

Что касается изотопного отношения $206 \mathrm{~Pb} / 238 \mathrm{U}$, для всех возрастов наклон его кривой стабильно пологий. Высокая природная распространенность изотопа ${ }^{238 U}$ обеспечивает при своем распаде высокое содержание ${ }^{206} \mathrm{~Pb}$. Благодаря этому отношение $206 \mathrm{~Pb} / 238 \mathrm{U}$ надежно анализируется масс-спектрометром и выдает наиболее достоверную оценку возраста.

Ввиду низкой скорости распада 232Тh изотопное отношение ${ }^{208} \mathrm{~Pb} / 232 \mathrm{Th}$ в течение геологического времени ( 4500 млн лет) изменяется минимально относительно других изотопных отношений. Линия зависимости изотопного отношения и возраста на рисунке 5 имеет крутой наклон и близка к прямой. Данная особенность говорит о том, что ошибка определения возраста может быть относительно большой, но стабильной для всех возрастов, независимо от того, молодые или древние. Благодаря тому, что ${ }^{232} \mathrm{Th}$ - единственный изотоп тория и имеет природную распространенность в 100 \%, соответственно, ${ }^{208} \mathrm{~Pb}$ и ${ }^{232} \mathrm{Th}$ дают хорошие аналитические сигналы, и определения возраста по отношению ${ }^{208} \mathrm{~Pb} /{ }^{232} \mathrm{Th}$ в некоторых случаях довольно надежны [Chew et al., 2011]. Однако основные сложности использования данного отношения для датирования цирконов обусловлены большой летучестью тория. Возможно, именно геохимической подвижностью тория объясняется существенное отклонение некоторых измерений от средневзвешенного возраста ${ }^{208} \mathrm{~Pb} /{ }^{232} \mathrm{Th}$ в цирконах Plešovice (см. рис. 4,2$)$.

Таким образом, на примере датирования циркона Plešovice LA-ICP-MS методом показано, что средневзвешенные значения возраста, рассчитанные по изотопным отношениям $206 \mathrm{~Pb} / 238 \mathrm{U}$ и $207 \mathrm{~Pb} / 235 \mathrm{U}$, совпадают с его аттестованным возрастом в пределах 2\%-ной ошибки, тогда как значения возраста по отношениям ${ }^{207} \mathrm{~Pb} / 206 \mathrm{~Pb}$ и ${ }^{208} \mathrm{~Pb} / 232 \mathrm{Th}$ отклоняются более чем на 2.5 \%. Данные отклонения средневзвешенных возрастов и величина ошибки их определения объясняются теоретическими построениями, основанными на периоде полураспада (постоянной распада), природной распространенности и геохимической подвижности изотопов. Однако нужно отметить, что значение конкордантного возраста не зависит от используемых пар изотопных отношений $206 \mathrm{~Pb} / 238 \mathrm{U}$ - $207 \mathrm{~Pb} / 235 \mathrm{U}$ (диаграмма Аренса-Везерилла) или ${ }^{207} \mathrm{~Pb} / 206 \mathrm{~Pb}$ -

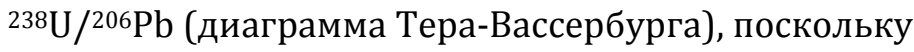
эти диаграммы математически эквивалентны. Далее для оценки конкордантного возраста цирконов из пород позднепалеозойской бимодальной дайко- вой ассоциации использованы только отношения ${ }^{206} \mathrm{~Pb} /{ }^{238} \mathrm{U}$ и ${ }^{207} \mathrm{~Pb} /{ }^{235} \mathrm{U}$.

\section{4. РЕЗУЛЬТАТЫ}

В рамках данного исследования было проведено датирование пяти проб цирконов, в том числе двух проб из трахитовых даек, одной пробы из трахибазальтовой дайки, пробы из базитовой краевой и пробы из центральной риолитовой части комбинированной дайки 2-го типа. Результаты приведены на рис. 6. Полная таблица измеренных изотопных отношений и возрастов доступна по запросу к М.Д. Буянтуеву (molon2@rambler.ru). Нужно отметить, что для возраста по ${ }^{206} \mathrm{~Pb} / 238 \mathrm{U}$ отношению проведена коррекция на обыкновенный свинец 207Pb-методом.

Из кварцевого трахита (проба М326) дайки опорного Онинского участка в бассейне р. Она выделены призматические идиоморфные прозрачные цирконы размером 100-200 мкм. Для них на основе измерения 15 зерен получен конкордантный воз-

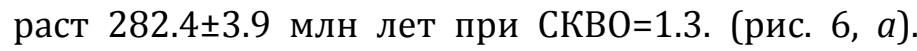
Корректированный средневзвешенный возраст по $206 \mathrm{~Pb} / 238 \mathrm{U}$ изотопному отношению составил $282.7 \pm 3.9$ млн лет (рис. 6, б). По данным измерений семи валовых проб салических даек Онинского участка и мономинеральной выборки биотита (из

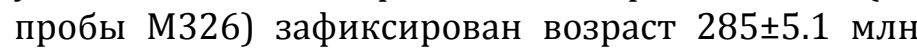
лет, $\left({ }^{87} \mathrm{Sr} /{ }^{86} \mathrm{Sr}\right)_{0}=0.70603 \pm 0.00047$ (СКВO=2.6) [Shadaev et al., 2005]. Изохрона биотит - вал (проба M326) показала Т $=281 \pm 40$ млн лет, $\left({ }^{87 \mathrm{Sr}} /{ }^{86 \mathrm{Sr}}\right)_{0}=$ $=0.70593 \pm 0.00055$.

Для кварцевого трахита (проба M516) из дайки опорного участка Жаргаланта в бассейне одноименного ручья на основе измерения 17 зерен цирконов получен конкордантный возраст 279 2.7 млн лет при СКВО=3.1 (рис. 6, в). Средневзвешенный $206 \mathrm{~Pb} / 238 \mathrm{U}$ изотопный возраст, корректированный на обыкновенный свинец 207Pb-методом, $276.7 \pm 2.8$ млн лет (рис. 6, 2). По внешнему виду и размеру данные кристаллы близки цирконам пробы М326. Для салических даек участка Жаргаланта полученный $\mathrm{Rb}-\mathrm{Sr}$ возраст по четырем определениям составляет $\mathrm{T}=300.7 \pm 4.7$ млн лет, $\left({ }^{87} \mathrm{Sr} /{ }^{86} \mathrm{Sr}\right)_{0}=$ $=0.70595 \pm 0.00025$ (СКВО=1.3) [Shadaev et al., 2005]. Двухточечная изохрона биотит - вал (M516) дает $\mathrm{T}=314 \pm 18$ млн лет, $\left({ }^{87} \mathrm{Sr} /{ }^{86} \mathrm{Sr}\right)_{0}=0.7056 \pm 0.00055$, что древнее $\mathrm{U}-\mathrm{Pb}$ датировки.

Нужно отметить, что изотопное датирование мафических даек ранее не проводилось, их возрастная позиция оценивалась только из геологических взаимоотношений с ассоциирующими породами, поэтому нами U-Pb LA-ICP-MS методом исследованы цирконы трахибазальтовой дайки из 

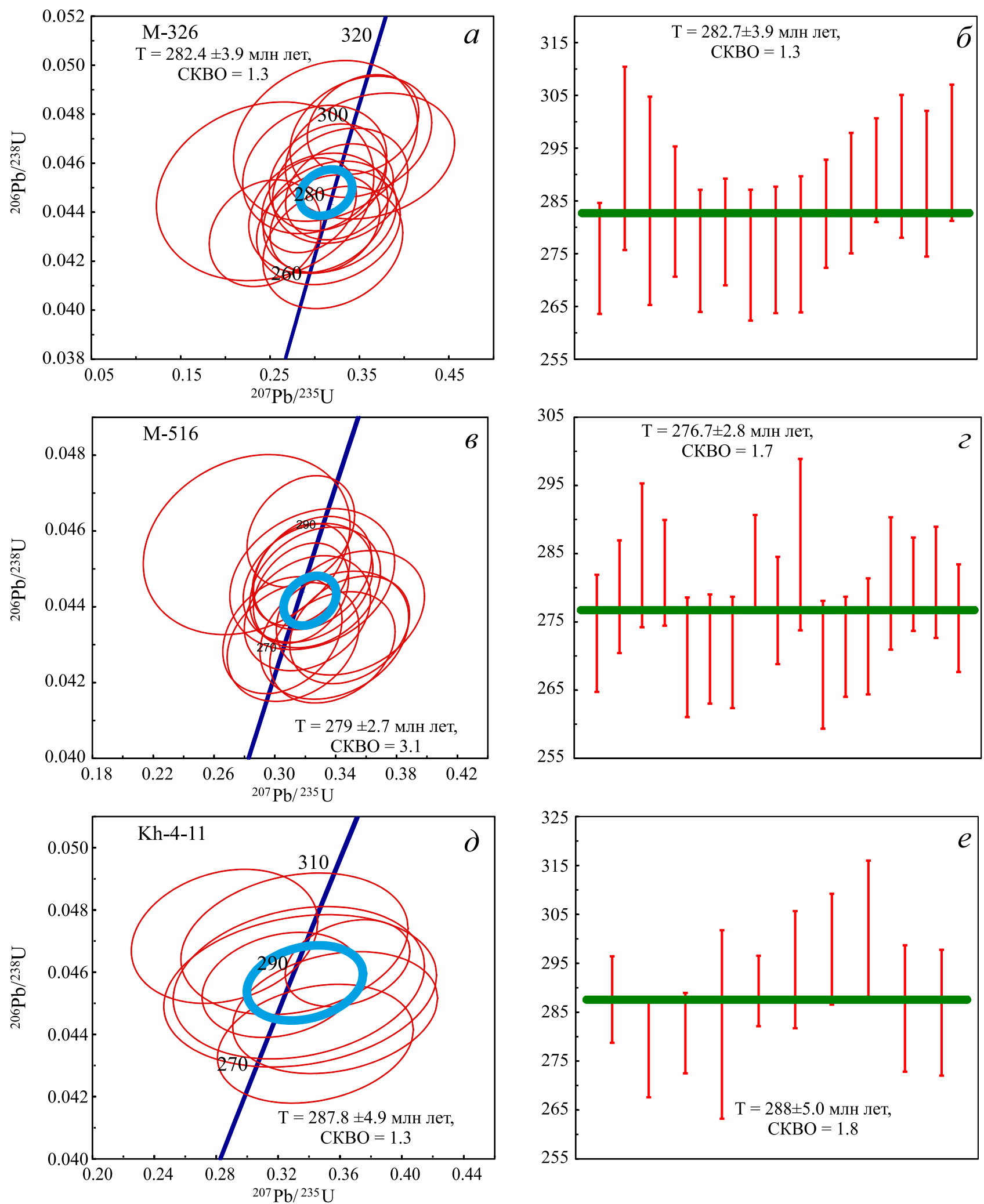

Рис. 6. Диаграммы с конкордией и диаграммы средневзвешенных ${ }^{206} \mathrm{~Pb} /{ }^{238} \mathrm{U}$ возрастов, корректированных на обыкновенный свинец ${ }^{207} \mathrm{~Pb}$-методом, для цирконов из простых даек позднепалеозойского дайкового пояса Западного Забайкалья: $a$, б - из кварцевого трахита опорного участка в бассейне р. Она; 8,2 - из кварцевого трахита опорного участка в бассейне р. Жаргаланта; $\partial$, $e$ - из трахибазальта Билютинского известнякового карьера. Эллипсы и планки погрешностей на уровне $2 \sigma$.

Fig. 6. Diagrams with concordia and average weighted ${ }^{206} \mathrm{~Pb} /{ }^{238} \mathrm{U}$ ages, corrected to ordinary lead by the $\mathrm{Pb}{ }^{207} \mathrm{method}$, for zircons from simple dykes of the Late Paleozoic Western Transbaikalia: $a, \sigma-$ quartz trachyte sampled on the reference site in the Ona river basin; $8, z$ - quartz trachyte sampled on the reference site in the Zhargalanta river basin; $\partial, e-$ trachybasalt from the Biluta limestone quarry. Ellipses and error bars are at the level $2 \sigma$. 

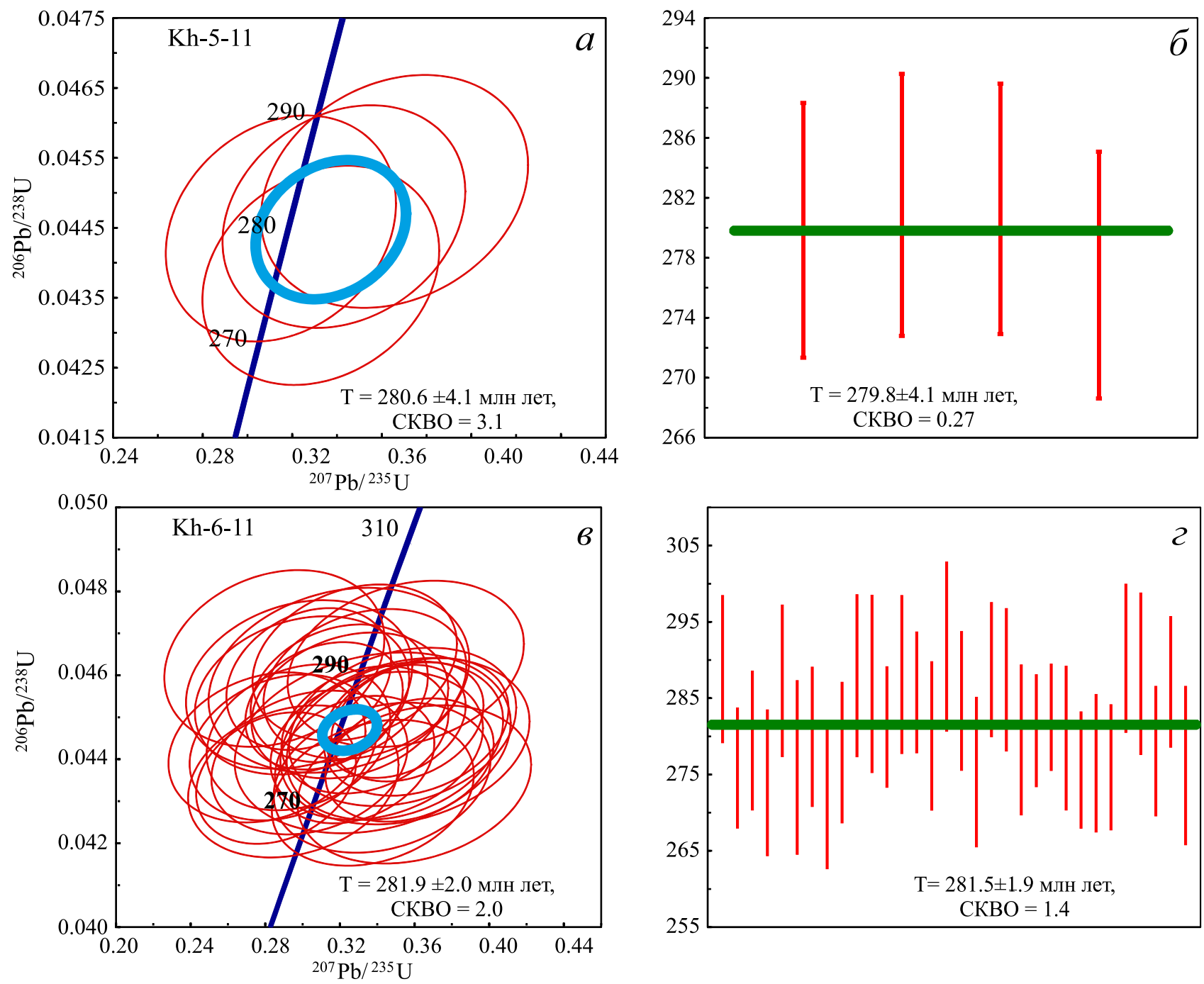

Рис. 7. Диаграммы с конкордией и диаграммы средневзвешенных ${ }^{206} \mathrm{~Pb} /{ }^{238} \mathrm{U}$ возрастов, корректированных на обыкновенный свинец 207Pb-методом, для цирконов из комбинированной дайки (Билютинский известняковый карьер) с признаками смешения контрастных магм с образованием промежуточных (средних) пород: $a$, б - из трахибазальта; в, г - из трахириолита. Эллипсы и планки погрешностей на уровне $2 \sigma$.

Fig. 7. Diagrams with concordia and average weighted ${ }^{206} \mathrm{~Pb} /{ }^{238} \mathrm{U}$ ages, corrected to ordinary lead by the $\mathrm{Pb}{ }^{207} \mathrm{method}$, for zircons from the combined dyke (Biluta limestone quarry) with indicators of mixing of contracting magmas followed by formation of intermediate rocks: $a, \sigma$ - from trachybasalt; 8,2 - fo trachyrhyolites. Ellipses and error bars are at the level $2 \sigma$.

Билютинского известнякового карьера. Из пробы трахибазальта Kh-4-11 было выделено десять прозрачных фрагментов кристаллов циркона размером не более 80 мкм. Получен конкордантный возраст 287.8 \pm 4.9 млн лет, СКВО=4.9 (рис. 6, д). Корректированный средневзвешенный возраст по ${ }^{206} \mathrm{~Pb} /{ }^{238} \mathrm{U}$ изотопному отношению составил $288 \pm 5$ млн лет (рис. 6, e).

Также из комбинированной дайки 2-го типа в центральной части карьера были выделены и проанализированы четыре обломанных кристалла циркона размером 50-90 мкм из трахибазальтового зальбанда и 32 идиоморфных кристалла из трахириолита центральной части. Конкордантный возраст для трахибазальта (Kh-5-11) - 280.6 44.1 млн лет, СКВО=3.1 (рис. 7, a), для трахириолита (Кh-6-11) - 281.9 2 млн лет, СКВО=2 (рис. 7, в). Корректированный средневзвешенный возраст на обыкновенный свинец ${ }^{207} \mathrm{~Pb}$-методом по ${ }^{206} \mathrm{~Pb} / 238 \mathrm{U}$ изотопному отношению составил для трахибазальта 279.8 \pm 4.1 млн лет (рис. 7, б), для трахириолита $281.5 \pm 1.9$ млн лет (рис. 7, 2). Для салических даек Билютинского карьера на основе $\mathrm{Rb}-\mathrm{Sr}$ изотопного измерения трех валовых проб и мономинеральных выборок биотита и калинатрового полевого шпата получена дата $\mathrm{T}=289 \pm 6$ млн лет, $\left({ }^{87} \mathrm{Sr} /{ }^{86} \mathrm{Sr}\right)_{0}=$ $=0.70586 \pm 0.00023$, СКВО $=0.28$. Возраст по валовой пробе В12 и мономинеральным фракциям K-Na по- 
левого шпата и биотита из этой пробы составляет $\mathrm{T}=288.7 \pm 6.6$ млн лет, $\left({ }^{87} \mathrm{Sr} /{ }^{86} \mathrm{Sr}\right)_{0}=0.70586 \pm 0.00032$, СКВО $=0.64$ [Хубанов, 2009].

\section{5. ОБСУЖДЕНИЕ}

Оценки возраста формирования бимодальной дайковой ассоциации с помощью U-Pb LA-ICP-MS метода практически, в пределах ошибки метода, совпадают c $\mathrm{Rb}-\mathrm{Sr}$ изохронными датами, полученными для салических даек участков Она и Билютинский карьер. Исключение составляет возраст салических даек участка Жаргаланта, для них $\mathrm{Rb}-\mathrm{Sr}$ возраст древнее, чем U-Pb датировка. Возможно, завышение $\mathrm{Rb}-\mathrm{Sr}$ изохронной даты обусловлено некоторой контаминацией кислых дайковых магм коровым субстратом с высоким содержанием радиогенного стронция. Тем не менее пермские возрасты дайковых пород, полученные U-Pb LA-ICP-MS методом, соответствуют геологическим наблюдениям: во-первых, дайки секут известково-щелочные граниты баргузинского комплекса (330-300 млн лет) и граниты зазинского комплекса (305-285 млн лет) [Tsygankov et al., 2007, 2010]; во-вторых, они пространственно сопряжены с пермскими гранитоидами повышенной щелочности (Брянский и Хоринский массивы) и бимодальными вулканитами с возрастом 285-280 млн лет [Posokhov et al., 2005; Litvinovsky et al., 2002; Riechow et al., 2010], a также близки к ним по своим вещественным характеристикам [Khubanov, 2009].

Наблюдаемые взаимные пересечения трахибазальтовых, трахитовых и трахириолитовых даек предполагают их одновозрастность, однако это не всегда очевидно из-за недостаточно детальной изученности, в том числе по причине плохой обнаженности. Прямым признаком сосуществования и взаимодействия контрастных магм являются комбинированные (сложные) дайки [Litvinovsky et al., 1995a; 1995b; Sklyarov, Fedorovskii, 2006; Katzir et al., 2007; Burmakina, Tsygankov, 2013]. Примером смешения магм является описанная выше комбинированная дайка в Билютинском карьере (см. рис. 2), в которой вполне ясно проявлены геологические, минералогические и геохимические свидетельства миксинга мафических и салических магм с образованием гибридных трахиандезитов и трахидацитов [Vrublevskaya et al., 2013].

Возраст цирконов из зальбандового трахибазальта (280.6 44.1 млн лет, проба Kh-5-11) и трахириолита центральной части этой комбинированной дайки (281.9 \pm 2 млн лет, проба Kh-6-11) в пределах погрешности метода совпадает. Эти датировки еще раз доказывают возможность химического смешения контрастных магм с образованием средних промежуточных пород. Даже если предположить, что цирконы попали в трахибазальтовую магму из трахириолитовой магмы, то и этот случай будет говорить об одновременном существовании и взаимодействии мафических и салических магм.

Таким образом, внутреннее строение дайкового пояса свидетельствует об условиях растяжения земной коры на момент его образования - это субпараллельное положение пакетированных даек с генеральным северо-восточным простиранием и комплексы «дайка в дайке». Подобные соотношения субвулканитов возникают в результате многократных инъекций магм в эпизодически расширяющуюся вертикальную полость при растяжении [Coleman, 1977; Stupak, 1990].

Бимодальный состав субвулканической серии, наличие комбинированных даек, а также изотопногеохронологические данные свидетельствуют об активной роли вещества мантии при формировании дайковой серии. Незначительная вариация состава мафических даек по простиранию пояса [Shadaev et al., 2005; Khubanov, 2009] говорит о том, что мантийный источник был геохимически относительно однородным.

Кроме того, региональные размеры пояса, который с перерывами прослеживается не менее чем на 200 км, и его пространственная и временная сопряженность с крупнейшими массивами гранитои-

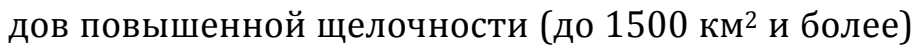
и полями бимодальных трахибазальт-трахит-комендитовых вулканитов предполагают, что в перми, на заключительной стадии позднепалеозойских магматических событий Западного Забайкалья, были заложены относительно крупные рифтогенные структуры, возможно по размерам и объему изверженного материла сопоставимые с мезозойскими проявлениями внутриплитного магматизма на данной территории.

\section{6. ЗАКЛЮЧЕНИЕ}

На примере стандарта Plešovice показано, что при датировании цирконов палеозойского возраста методом LA-ICP-MS наиболее достоверные оцен-

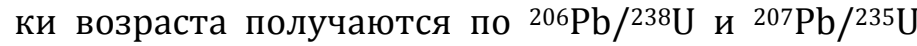
изотопным отношениям. Некорректность определения возраста по ${ }^{207} \mathrm{~Pb} /{ }^{206} \mathrm{~Pb}$ для фанерозойских цирконов обусловлена относительно низким содержанием радиогенных свинцов и высокой степенью зависимости от правильности определения данного отношения, поскольку даже незначительное отклонение изотопного отношения от истинного значения приводит к существенному искажению возраста, тогда как основные сложности использования ${ }^{208} \mathrm{~Pb} /{ }^{232} \mathrm{Th}$ отношения для датирова- 
ния цирконов обусловлены большой летучестью тория.

Геологическое строение дайкового пояса свидетельствует об условиях растяжения земной коры на момент его формирования. Полученные возрасты (290-280 млн лет) становления дайкового пояса в совокупности с данными о возрасте ассоциирующих гранитоидов повышенной щелочности указывают на развитие рифтогенеза на заключительном этапе позднепалеозойского гранитоидного магматизма Западного Забайкалья.

Близость U-Pb изотопных возрастов цирконов из трахибазальтового зальбанда и трахириолитовой центральной части симметрично-зональной комбинированной дайки в Билютинском известняковом карьере подтверждает геологические, минералогические и геохимические данные о смешении контрастных магм при ее становлении с образованием пород промежуточного, среднего, состава.

\section{7. БЛАГОДАРНОСТИ}

Авторы выражают признательность анонимным рецензентам за конструктивные замечания. Статья подготовлена при поддержке Российского фонда фундаментальных исследований (проекты № 1405-00498 и 17-05-00275).

\section{8. ЛИТЕРАTУРA / REFERENCES}

Black L.P., Kamo S.L., Allen C.M., Davis D.W., Aleinikoff J.N., Valley J.W., Mundil R., Campbell I.H., Korsch R.J., Williams I.S., Foudoulis $C$., 2004. Improved ${ }^{206} \mathrm{~Pb} /{ }^{238} \mathrm{U}$ microprobe geochronology by the monitoring of a trace-element-related matrix effect; SHRIMP, ID-TIMS, ELA-ICP-MS and oxygen isotope documentation for a series of zircon standards. Chemical Geology 205 (1-2), 115-140. https://doi.org/10.1016/j.chemgeo.2004.01.003.

Burmakina G.N., Tsygankov A.A., 2013. Mafic microgranular enclaves in Late Paleozoic granitoids in the Burgasy quartz syenite massif, western Transbaikalia: Composition and petrogenesis. Petrology 21 (3), 280-303. https://doi.org/ 10.1134/S086959111303003X.

Chew D.M., Sylvester P.J., Tubrett M.N., 2011. U-Pb and Th-Pb dating of apatite by LA-ICPMS. Chemical Geology 280 (1-2), 200-216. https://doi.org/10.1016/j.chemgeo.2010.11.010.

Coleman R.G., 1977. Ophiolites. Springer, New York, 229 р. [Русский перевод: Колман Р.Г. Офиолиты. М.: Мир, 1979. 262 c.].

Gehrels G.E., Valencia V.A., Ruiz J., 2008. Enhanced precision, accuracy, efficiency, and spatial resolution of U-Pb ages by laser ablation - multicollector - inductively coupled plasma - mass spectrometry. Geochemistry, Geophysics, Geosystems 9 (3), Q03017. https://doi.org/10.1029/2007GC001805.

Griffin W.L., Powell W.J., Pearson N.J., O'Reilly S.Y., 2008. GLITTER: data reduction software for laser ablation ICP-MS In: P.J. Sylvester (Ed.), Laser ablation ICP-MS in the Earth sciences: current practices and outstanding issues. Mineralogical association of Canada short course series, vol. 40, p. 204-207.

Hirata T., Iizuka T., Orihashi Y., 2005. Reduction of mercury background on ICP-mass spectrometry for in situ U-Pb age determinations of zircon samples. Journal of Analytical Atomic Spectrometry 20 (8), 696-701. https://doi.org/ 10.1039/B504153H.

Katzir Y., Litvinovsky B.A., Jahn B.M., Eyal M., Zanvilevich A.N., Valley J.W., Vapnik Ye, Beeri Y., Spicuzza M.J., 2007. Interrelations between coeval mafic and A-type silicic magmas from composite dykes in a bimodal suite of southern Israel, northernmost Arabian-Nubian Shield: geochemical and isotope constraints. Lithos 97 (3-4), 336-364. https://doi.org/10.1016/j.lithos.2007.01.004

Khubanov V.B., 2009. The Bimodal Dike Belt in the Central Part of the Western Transbaikalia: Geological Structure, Age, Composition and Petrogenesis. PhD Thesis (Geology and Mineralogy). Ulan-Ude, 176 p. (in Russian) [Хубанов В.Б. Бимодальный дайковый пояс центральной части Западного Забайкалья: геологическое строение, возраст, состав и петрогенезис: Дис. ... канд. геол.-мин. наук. Улан-Удэ, 2009. 176 с.].

Khubanov V.B., Buyantuev M.D., Tsygankov A.A., 2016. U-Pb dating of zircons from $\mathrm{PZ}_{3}-\mathrm{MZ}$ igneous complexes of Transbaikalia by sector-field mass spectrometry with laser sampling: technique and comparison with SHRIMP. Russian Geology and Geophysics 57 (1), 190-205. https://doi.org/10.1016/j.rgg.2016.01.013.

Khubanov V.B., Vrublevskaya T.T., Tsyrenov B.Ts., Tsygankov A.A., 2015. Formation of the trachybasalt-trachyte bimodal series of the Malo-Khamardaban volcanotectonic complex, Southwestern Transbaikalia: role of fractional crystallization and magma mixing. Petrology 23 (5), 451-479. https://doi.org/10.1134/S0869591115040037.

Košler J., Sylvester P.J., 2003. Present trends and the future of zircon in geochronology: laser ablation ICPMS. Reviews in Mineralogy and Geochemistry 53 (1), 243-275. https://doi.org/10.2113/0530243.

Litvinovsky B.A., Jahn B.-M., Zanvilevich A.N., Titov A.V., 2002. Petrogenesis of syenite-granite suites from the Bryansky complex (Transbaikalia, Russia): Implications for the origin of A-type granitoid magmas. Chemical Geology 189 (1), 105-133. https://doi.org/10.1016/S0009-2541(02)00142-0.

Litvinovsky B.A., Zanvilevich A.N., Alakshin A.M., Podladchikov Y.Y., 1993. The Angara-Vitim Batholith, the Largest Granitoid Pluton. OIGGM SO RAN, Novosibirsk, 141 p. (in Russian) [Литвиновский Б.А., Занвилевич А.Н., Алак- 
шин А.М., Подладчиков Ю.Ю. Ангаро-Витимский батолит - крупнейший гранитоидный плутон. Новосибирск: Изд-во ОИГГМ СО РАН, 1993. 141 с.].

Litvinovsky B.A., Zanvilevich A.N., Kalmanovich M.A., 1995a. Multiple mixing of coexisting syenitic and basaltic magmas and its petrological implications, Ust'-Khilok massif, Transbaikalia. Petrologiya (Petrology) 3 (2), 133-157 (in Russian) [Литвиновский Б.А., Занвилевич А.Н., Калманович М.А. Многократное смешение сосуществующих сиенитовых и базитовых магм и его петрологическое значение, Усть-Хилокский массив, Забайкалье // Петрология. 1995. Т. 3. № 2. С. 133-157].

Litvinovsky B.A., Zanvilevich A.N., Lyapunov S.M., Bindeman I.N., Davis A.M., Kalmanovich M.A., 1995b. Model of composite basite-granitoid dike generation (Shaluta Pluton, Transbaikalia). Geologiya i Geofizika (Russian Geology and Geophysics) 36 (7), 3-22 (in Russian) [Литвиновский Б.А., Занвилевич А.Н., Ляпунов С.М., Биндеман И.Н., Дэвис А.М., Калманович М.А. Условия образования комбинированных базит-гранитных даек (Шалутинский массив, Забайкалье) // Геология и геофизика. 1995. Т. 36. № 7. С. 3-22].

Ludwig K.R., 2008. User's Manual for Isoplot 3.70: A Geochronological Toolkit for Microsoft Excel. Berkeley Geochronology Center, Berkeley, $76 \mathrm{p}$.

Posokhov V.F., Shadaev M.G., Litvinovsky B.A., Zanvilevich A.N., Khubanov V.B., 2005. Rb-Sr age and sequence of formation of granitoids of the Khorinka volcanoplutonic structure in the Mongolo-Transbaikalian belt. Geologiya $i$ Geofizika (Russian Geology and Geophysics) 46 (6), 612-619.

Reichow M.K., Litvinovsky B.A., Parrish R.R., Saunders A.D., 2010. Multi-stage emplacement of alkaline and peralkaline syenite-granite suites in the Mongolian-Transbaikalian belt, Russia: evidence from U-Pb geochronology and whole-rock geochemistry. Chemical Geology 273 (1-2), 120-135. https://doi.org/10.1016/j.chemgeo.2010.02. 017.

Shadaev M.G., Khubanov V.B., Posokhov V.F., 2005. New data on the Rb-Sr age of dike belts in Western Transbaikalia. Geologiya i Geofizika (Russian Geology and Geophysics) 46 (7), 707-715.

Sklyarov E.V., Fedorovskii V.S., 2006. Magma mingling: tectonic and geodynamic implications. Geotectonics 40 (2), 120-134. https://doi.org/10.1134/S001685210602004X.

Sláma J., Košler J., Condon D.J., Crowley J.L., Gerdes A., Hanchar J.M., Horst-wood M.S.A., Morris G.A., Nasdala L., Norberg N., Schaltegger U., Schoene B., Tubrett M.N., Whitehouse M.J., 2008. Plešovice zircon - A new natural reference material for U-Pb and Hf isotopic microanalysis. Chemical Geology 249 (1-2), 1-35. https://doi.org/10.1016/j.chemgeo. 2007.11.005.

Stacey J.S., Kramers J.D., 1975. Approximation of terrestrial lead isotope evolution by a two-stage model. Earth and Planetary Science Letters 26 (2), 207-221. https://doi.org/10.1016/0012-821X(75)90088-6.

Stupak F.M., 1990. Structure of continental spreading zones (case of the Vitim dike belt, Transbaikalia). Doklady AN SSSR 312 (2), 447-450 (in Russian) [Ступак Ф.М. Строение континентальных спрединговых зон (на примере Витимского дайкового пояса Забайкалья) // Доклады АН СССР. 1990. Т. 312. № 2. С. 447-450].

Tsygankov A.A., Litvinovsky B.A., Jahn B.M., Reichow M.K., Liu D.Y., Larionov A.N., Presnyakov S.L., Lepekhina Ye.N., Sergeev S.A., 2010. Sequence of magmatic events in the Late Paleozoic of Transbaikalia, Russia (U-Pb isotope data). Russian Geology and Geophysics 51 (9), 972-994. https://doi.org/10.1016/j.rgg.2010.08.007.

Tsygankov A.A., Matukov D.I., Berezhnaya N.G., Larionov A.N., Posokhov V.F., Tsyrenov B.T., Khromov A.A., Sergeev S.A., 2007. Late Paleozoic granitoids of western Transbaikalia: magma sources and stages of formation. Russian Geology and Geophysics 48 (1), 120-140. https://doi.org/10.1016/j.rgg.2006.12.011.

Van Achterbergh E., Ryan C.G., Jackson S.E., Griffin W.L., 2001. Data reduction software for LA-ICP-MS. In: P.J. Sylvester (Ed.), Laser-ablation-ICPMS in the Earth sciences - principles and applications. Mineralogical association of Canada short course series, vol. 29, p. 239-243.

Vrublevskaya T.T., Khubanov V.B., Tsyrenov B.T., 2013. Formation of trachyandesites and trachydatsites by mixing of contrasting magmas in complex dikes (Western Transbaikalia). Otechestvennaya Geologiya (Russian Geology) (3), 55-64 (in Russian) [Врублевская Т.Т., Хубанов В.Б., Цыренов Б.Ц. Образование трахиандезитов и трахидацитов при смешении контрастных магм в сложных дайках (Западное Забайкалье) // Отечественная геология. 2013. № 3. С. 55-64].

Wiebe R.A., Ulrich R., 1997. Origin of composite dikes in the Gouldsboro granite, coastal Maine. Lithos 40 (2-4), 157-178. https://doi.org/10.1016/S0024-4937(97)00008-X.

Wiedenbeck M., Allé P., Corfu F., Griffin W.L., Meier M., Oberli F., von Quadt A., Roddick J.C., Spiegel W., 1995. Three natural zircon standards for U-Th-Pb, Lu-Hf, trace element and REE analysis. Geostandards Newsletter 19 (1), 1-23. https://doi.org/10.1111/j.1751-908X.1995.tb00147.x.

Williams I.S., 1998. U-Th-Pb geochronology by ion microprobe. In: M.A. McKibben, W.C. Shanks III, W.I. Ridley (Eds.), Applications of microanalytical techniques to understanding mineralizing processes. Reviews in Economic Geology, vol. 7, p. 1-35. https://doi.org/10.5382/Rev.07.01.

Yarmolyuk V.V., Ivanov V.G., Kovalenko V.I., 1998. Sources of intraplate magmatism of Western Transbaikalia in the Late Mesozoic - Cenozoic: trace-element and isotope data. Petrology 6 (2), 101-123.

Zanvilevich A.N., Litvinovsky B.A., Andreev G.V., 1985. The Mongolian-Transbaikalian Alkaline-Granitoid Province. Nauka, Moscow, 232 p. (in Russian) [Занвилевич А.Н., Литвиновский Б.А., Андреев Г.В. Монголо-Забайкальская щелочно-гранитоидная провинция. М.: Наука, 1985. 232 с.]. 

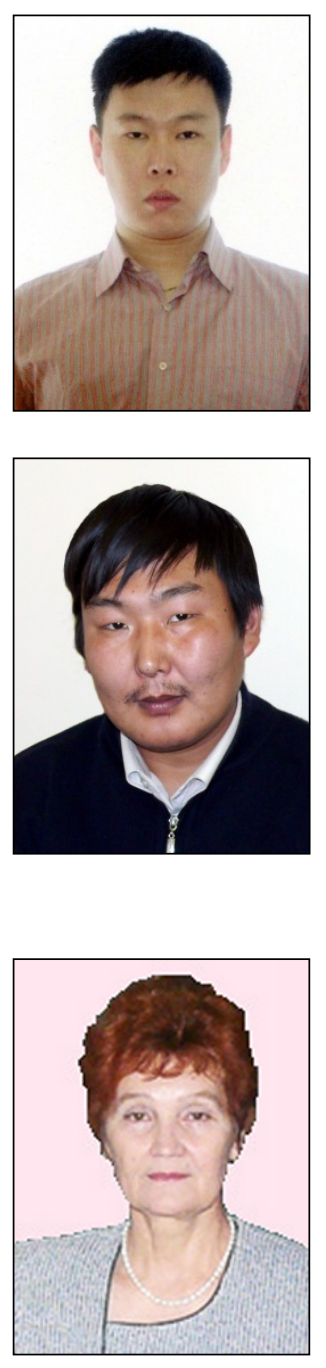

Буянтуев Молон Димитович, м.н.с.

Геологический институт СО РАН

670047, Улан-Удэ, ул. Сахьяновой, 6а, Россия

$\checkmark$ e-mail: molon2@rambler.ru

Buyantuev, Molon D., Junior Researcher Geological Institute, Siberian Branch of RAS 6a Sakhyanova street, Ulan-Ude 670047, Russia e-mail: molon2@rambler.ru

Хубанов Валентин Борисович, канд. геол.-мин. наук, с.н.с. Геологический институт СО РАН

670047, Улан-Удэ, ул. Сахьяновой, 6а, Россия

Бурятский государственный университет

670000, Улан-Удэ, ул. Смолина, 24a, Россия

e-mail: khubanov@mail.ru

Khubanov, Valentin B., Candidate of Geology and Mineralogy, Senior Researcher Geological Institute, Siberian Branch of RAS

6a Sakhyanova street, Ulan-Ude 670047, Russia

Buryat State University

24a Smolin street, Ulan-Ude 670000, Russia

e-mail:khubanov@mail.ru

Врублевская Татьяна Тимофеевна, канд. геол.-мин. наук, с.н.с.

Геологический институт СО РАН

670047, Улан-Удэ, ул. Сахьяновой, 6а, Россия

Бурятский государственный университет

670000, Улан-Удэ, ул. Смолина, 24a, Россия

e-mail: vrublevskayatt@rambler.ru

Vrublevskaya, Tatiana T., Candidate of Geology and Mineralogy, Senior Researcher Geological Institute, Siberian Branch of RAS

6a Sakhyanova street, Ulan-Ude 670047, Russia

Buryat State University

24a Smolin street, Ulan-Ude 670000, Russia

e-mail: vrublevskayatt@rambler.ru 